University of

New Hampshire

Carsey School of

Public Policy

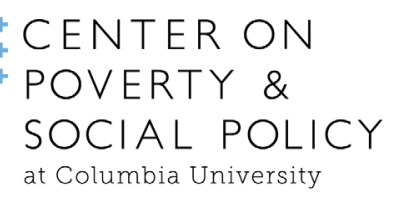

at Columbia University

DATA

SNAPSHOT

December 15, 2017

\title{
Poorer Working Families With Young Children Are Unlikely to Afford Child Care
}

\author{
Robert Paul Hartley, Marybeth J. Mattingly, and Christopher Wimer
}

Low-income families with working parents face significant burdens paying for child care, which can function as a barrier to work and often means parents must rely on child care arrangements that are less formal and less stable. ${ }^{1}$ Amid national concerns about the high cost of child care, it is important to keep this issue at the forefront. Given the especially high costs of care for very young children, this snapshot highlights the child care costs faced by families with a child under age 3 . Figure 1 shows the share of families paying for child care (bottom sections) by their income level. As a family's income-to-poverty ratio rises, they are more likely to pay for child care. Poorer families who do pay for child care are much more often paying over 7 percent of their income on child care, the current benchmark of affordability from the U.S. Department of Health and Human Services. ${ }^{2}$

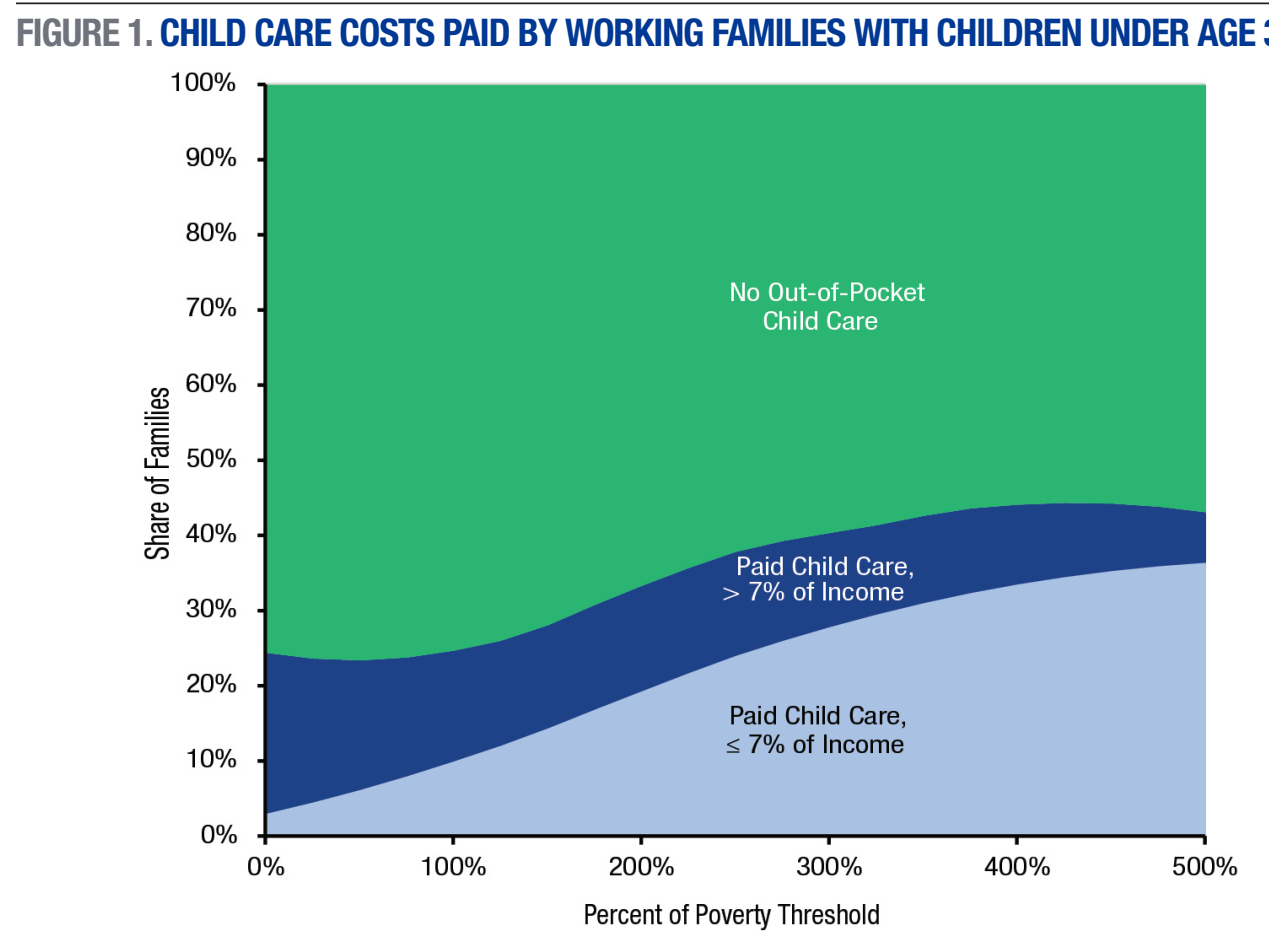

Source: 2012-2016 Current Population Survey, Annual Social and Economic Supplement
Poor working families with children under age 3 pay, on average, over $1 / 4$ of their total income on child care.

\section{See related publications}

- Child Care Costs and Poverty Among Families With Young Children (October 2017)

Child Care Expenses Push Many Families Into Poverty (May 2017)

Child Care Costs Exceed 10 Percent of Family Income for One in Four Families (November 2016)
Endnotes
1. W. Primus and K. Daugirdas, "Reducing Child Poverty by Improving the Work-Based Safety Net," in For Better or Worse: Welfare Reform and the Well-Being of Children and Families, edited by G.J. Duncan and L.P. Chase-Lansdale (New York: Russell Sage Foundation, 2001), 253.
2. U.S. Department of Health and Human Services, "Child Care and Development Fund (CCDF) Program," 81 Fed. Reg. 67438 (September 30, 2016), https:// www.federalregister.gov/d/2016- 22986/p-355. 